\title{
PENATALAKSANAAN PASIEN DEMAM TIFOID RAWAT INAP DI RSUD H. ABDUL MANAN SIMATUPANG KISARAN
}

\author{
Armon Rahimi*, Antje Irmella Tarigan, Adhayani Lubis \\ Fakultas Kedokteran Universitas Prima Indonesia \\ *Korespondensi: armonrahimi@yahoo.com
}

\begin{abstract}
ABSTRAK
Kejadian demam tifoid di Indonesia sekitar 760-810 kasus per 100.000 penduduk setiap tahunnya, dengan angka kematian 3,1-10,4\%. Penelitian ini bertujuan untuk mengetahui gambaran diagnostik dan penatalaksanaan pasien demam tifoid rawat inap. Penelitian ini merupakan penelitian deskriptif dengan desain studi kasus. Populasi seluruh data pasien demam tifoid rawat inap di RSUD H. Abdul Manan Simatupang Kisaran dan jumlah sampel yang ditentukan sebanyak 100 data yang diambil oleh petugas rekam medik. Penelitian ini menyimpulkan keluhan utama tertinggi pada pasien demam tifoid adalah demam (91\%) dan keluhan tambahan tertinggi mual (76\%). Berdasarkan jenis pemeriksaan, pemeriksaan fisik yang tertinggi adalah pemeriksaan pada lidah tifoid (68\%), pemeriksaan darah rutin yang tertinggi dengan leukopenia (65\%). Pemeriksaan serologis pada semua pasien yaitu uji widal (+) $89 \%$ dan uji tubex (+) 11\%. Terapi cairan diberikan kepada semua pasien yaitu terapi RL(85\%) dan NaCL (15\%). Sedangkan pada lama rawatan, rata-rata 6 hari (minimum 2 hari dan maksimum 12 hari). Outcome perawatan paling banyak adalah pulang berobat jalan (49\%). Status komplikasi tidak tercacat sehingga disarankan untuk lebih memperhatikan kelengkapan pada status data rekam medis.
\end{abstract}

Kata kunci: demam tifoid, penatalaksanaan

\begin{abstract}
The incidence of typhoid fever in Indonesia is around 760-810 cases per 100,000 population every year, with a mortality rate of $3.1-10.4 \%$. This study determines the diagnostic picture and management of typhoid fever patients hospitalized. This research is a descriptive research with a case study design. The population of all patients with typhoid fever inpatients at RSUD H. Abdul Manan Simatupang Kisaran and the number of samples determined is 100 data taken by medical record officers. This study concluded that the highest chief complaint in patients with typhoid fever was fever (91\%) and the highest additional complaint was nausea (76\%). Based on the type of examination, the highest physical examination was an examination of the typhoid tongue (68\%), routine blood examination, the highest with leukopenia (65\%). Serological examination in all patients was Widal test (+) $89 \%$ and tubex test (+) $11 \%$. Fluid therapy was given to all patients, namely $R L$ (85\%) and NaCL (15\%). While the length of treatment, the average is 6 days (minimum 2 days and maximum 12 days). The most treatment outcome was going home for outpatient treatment (49\%). Complication status is not disabled so it is advisable to pay more attention to the completeness of the status of medical record data.
\end{abstract}

Keywords: typhoid fever, management

\section{PENDAHULUAN}

Demam tifoid adalah infeksi akut pada saluran pencernaan yang disebabkan oleh Salmonella typhi. Demam parathyphi adalah penyakit sejenis yang disebabkan oleh Salmonella paratyphi A, B dan C. Gejala dan tanda kedua penyakit tersebut hampir sama, tetapi manifestasi klinis parathyphi lebih ringan. Kedua penyakit di atas disebut tifoid. Terminologi lain yang sering digunakan adalah typhoid fever, paratyphoid fever, tyhpus, dan paratyhpus abdominal atau demam enterik. ${ }^{1}$

Besarnya angka pasti kasus demam tifoid di dunia sangat sulit ditentukan karena penyakit ini dikenal mempunyai gejala dengan spektrum klinis yang sangat luas. Dari laporan World Health Organization (2003) terdapat 17 juta kasus demam tifoid per tahun di dunia dengan jumlah kematian mencapai 600.000 kematian dengan Case Fatality Rate (CFR=3,5\%). Tingkat kejadian penyakit demam tifoid di daerah endemis berkisar antara 45 per 100.000 penduduk per tahun sampai 1.000 per 100.000 penduduk per tahun. ${ }^{2}$

Hingga saat ini penyakit demam tifoid masih merupakan masalah kesehatan di negara-negara tropis termasuk Indonesia. Kejadian demam tifoid di dunia sekitar 16 juta kasus setiap tahunnya, 7 
juta kasus terjadi di Asia Tenggara, dengan angka kematian 600.000. Di Belanda kejadian demam tifoid hanya $0,4-0,7$ per 100.000 setiap tahunnya. ${ }^{3}$ Berdasarkan Profil Kesehatan Indonesia tahun 2012, demam tifoid atau paratifoid juga menempati urutan ke-3 dari 10 penyakit terbanyak dari pasien rawat inap di rumah sakit tahun 2010 yaitu sebanyak 41.081 kasus dan yang meninggal 274 orang dengan Case Fatality Rate sebesar 0,67 \%. ${ }^{4}$ Kejadian demam tifoid di Indonesia sekitar 760810 kasus per 100.000 penduduk setiap tahunnya, dengan angka kematian 3,1-10,4\%. ${ }^{3}$

Dinas Kesehatan Propinsi Sumatera Utara tahun 2009 melaporkan bahwa proporsi demam tifoid dari 10 penyakit terbanyak pasien rawat inap di rumah sakit yaitu 8,5\% (1.681 kasus) dari 19.870 kasus. Menurut Laporan Surveilans Terpadu Penyakit Berbasis Rumah Sakit di Sumatera Utara tahun 2008, jumlah kasus demam tifoid rawat inap yaitu 1.364 kasus. Berdasarkan Profil Kesehatan Sumatera Utara tahun 2008, demam tifoid yang rawat jalan dirumah sakit menempati urutan ke-5 dari 10 penyakit terbesar yaitu 661 penderita dari 12.876 pasien rawat jalan $(5,1 \%)$, sedangkan rawat inap di rumah sakit menempati urutan ke-2 dari 10 penyakit terbesar yaitu sebanyak 1.276 penderita dari 11.182 pasien rawat inap $(11,4 \%)^{5}$

Gejala demam tifoid dapat sangat bervariasi. Semula terjadi demam dengan kenaikan suhu secara bertahap dalam tiga hari pertama, nyeri kepala terus menerus, perut kembung dan nyeri, anoreksia, mual dan obstipasi. Kemudian sering kali disusul dengan diare, perdarahan hidung, apatis dan gejala psikis. Dalam penentuan diagnosis demam tifoid harus dilakukan pemeriksaan laboratorium karena pasien sering mengalami penurunan sel darah putih, anemia rendah karena perdarahan pada usus, jumlah trombosit menurun dari keadaan normal dan menemukan bakteri Salmonella typhosa pada kotoran, darah dan urin. ${ }^{6}$ Untuk diagnosis dilakukan berdasarkan riwayat penyakitnya dan pemeriksaan. Diagnosis dapat dilakukan dengan dijumpainya sel darah putih, bakteri tifoid dalam darah (kultur darah) dan meningkatnya antibodi dalam darah. ${ }^{7}$

Pada dasarnya tatacara diagnostik dan tatalaksana demam tifoid sudah diketahui, namun dengan adanya perkembangan teknologi ilmu kedokteran maka bisa saja tata cara diagnostik dan tata laksana demam tifoid bervariasi. Penelitian ini dilakukan untuk mengetahui gambaran diagnostik dan penatalaksanaan penderita demam tifoid rawat inap.

\section{METODE}

Penelitian ini merupakan penelitian deskriptif retrospektif dengan desain case study. Penelitian ini mendeskripsikan gambaran diagnostik dan penatalaksanaan pasien demam tifoid dengan melihat data sekunder atau rekam medik pasien demam tifoid rawat inap di RSUD H. Abdul Manan Simatupang. Populasi penelitian adalah seluruh pasien demam tifoid yang dirawat inap. Sesuai dengan tujuan penelitian untuk mengetahui proporsi maka besar sampel yang dibutuhkan adalah minimal 100 rekam medis. Cara pengambilan sampel adalah jika jumlah populasi lebih dari 100 rekam medis maka pengambilan sampel dengan metode purposive sampling yaitu dipilih data yang paling lengkap sesuai dengan kebutuhan. Jika populasi \pm 100 rekam medis dilakukan sampling dengan total populasi. Data univariat dianalisa dengan deskriptif statistik dan disajikan dalam bentuk narasi dan tabel distribusi proporsi.

\section{HASIL DAN PEMBAHASAN}

Pada tabel 1 dapat dilihat proporsi tertinggi pada kelompok umur 17-21 (41\%) dan 12-16 $(30 \%)$, sedangkan kelompok umur terendah 37-41 (3\%). Proporsi tertinggi pada kelompok jenis kelamin laki-laki yaitu 66 orang $(66 \%)$, sedangkan proporsi terendah yaitu kelompok jenis kelamin perempuan 34 orang (34\%). Insidens di Indonesia demam tifoid banyak dijumpai pada populasi yang berusia 3-19 tahun. ${ }^{8}$

Tabel 1. Karakteristik umum $(n=100)$

\begin{tabular}{lcc}
\hline Karakteristik & $\mathbf{n}$ & $\mathbf{( \% )}$ \\
\hline Umur & & \\
$12-16$ & 30 & 30 \\
$17-21$ & 41 & 41 \\
$22-26$ & 7 & 7 \\
$27-31$ & 5 & 5 \\
$32-36$ & 9 & 9 \\
$37-41$ & 3 & 3 \\
$42-46$ & 5 & 5 \\
Jenis kelamin & & \\
$\quad$ Perempuan & 34 & 34 \\
Laki-laki & 66 & 66 \\
\hline
\end{tabular}

Tabel 2. Proporsi pasien demam tifoid rawat inap berdasarkan keluhan $(n=100)$

$$
\text { Karakteristik }
$$

Keluhan utama 


\begin{tabular}{lcc} 
Demam & 91 & 91 \\
$\begin{array}{l}\text { Diare } \\
\text { Keluhan tambahan }\end{array}$ & 9 & 9 \\
Mual & 76 & 76 \\
Muntah & 50 & 50 \\
Konstipasi & 6 & 6 \\
Nyeri otot & 17 & 17 \\
Batuk & 50 & 50 \\
Sakit kepala & 24 & 24 \\
Nyeri epigastrium & 10 & 10 \\
Lemas & 40 & 40 \\
\hline
\end{tabular}

Keluhan utama yang paling banyak adalah demam (91\%), dan yang terendah adalah diare (9\%) (Tabel 2). Keluhan utama pasien demam tifoid berbeda-beda, tidak semua pasien datang dengan keluhan utama demam, sehingga keluhan demam tidak semua tercatat di dalam kartu rekam medik sebagai keluhan utama. Hal ini sesuai dengan penelitian yang dilakukan oleh Nainggolan RNF (2009) yang menunjukkan bahwa keluhan utama yang tertinggi adalah demam (100\%) dan terendah anoreksia $(0,7 \%) .{ }^{9}$ Pada minggu pertama gejala klinis penyakit ini ditemukan keluhan dan gejala serupa dengan penyakit infeksi lainnya yaitu demam, mual, muntah, obstipasi atau diare,perasaan tidak enak di perut dan batuk. ${ }^{8}$

Selain keluhan utama, pasien demam tifoid juga memiliki beberapa keluhan tambahan seperti mual, muntah, konstipasi, nyeri otot dan sebagainya. keluhan tambahan yang tertinggi adalah mual $(76 \%)$ diikuti muntah $(50 \%)$ dan yang terendah adalah konstipasi (6\%).

Pada pemeriksaan demam tifoid dilakukan pemeriksaan fisik yaitu untuk menemukan tanda klinis penyakit pada pasien demam tifoid. Pemeriksaan fisik tertinggi adalah lidah tifoid $(68 \%)$, meteorismus $(24 \%)$, dan terendah adalah rose spot $(2 \%)$. Selain didapatkan keluhan utama demam yang bersifat makin naik setiap hari, disertai dengan keluhan tambahan berupa lemah badan (lesu), nyeri kepala, nyeri otot punggung dan sendi, perut kembung kadang-kadang nyeri , konstipasi (kadang-kadang diare), mual muntah dan batuk. ${ }^{3}$

Dalam minggu kedua gejala-gejala menjadi lebih jelas berupa demam, bradikardi relatif (bradikardi relatif adalah peningkatan suhu 10C tidak di ikuti peningkatan denyut nadi 8 kali per menit), lidah yang berselaput (kotor ditengah, tepi dan ujung merah serta tremor), hepatomegali, splenomegali dan meteroismus. ${ }^{8}$

Tabel 3. Proporsi pasien demam tifoid rawat inap

\begin{tabular}{lcc}
\multicolumn{3}{c}{ berdasarkan jenis pemeriksaan $(\mathrm{n}=100)$} \\
\hline \multicolumn{1}{c}{ Karakteristik } & $\mathbf{n}$ & $\%$ \\
\hline Pemeriksaan fisik & 68 & 68 \\
Lidah Tifoid & 2 & 2 \\
Rose Spot & 5 & 5 \\
Hepatomegali & 4 & 4 \\
Splenomegali & 24 & 24 \\
$\quad$ Meteorismus & & \\
Pemeriksaan laboratorium & 65 & 65 \\
$\quad$ Leukopenia & 20 & 20 \\
$\quad$ Trombositopenia & 7 & 7 \\
Limpositosis & 8 & 8 \\
Eosinofilia & & \\
Pemeriksaan serologis & 89 & 89 \\
$\quad$ Uji Widal $(+)$ & 11 & 11 \\
Uji Tubex $(+)$ & &
\end{tabular}

Pemeriksaan darah rutin pada pasien demam tifoid dapat berupa leukopenia, limfositosis, trombositopenia dan eosinofilia. Pemeriksaan darah rutin tertinggi leukopenia (65\%) diikuti trombositopenia (20\%) dan terendah adalah limfositosis (7\%). Walaupun pada pemeriksaan darah perifer lengkap sering ditemukan leukopenia dapat pula terjadi leukositosis. Leukositosis dapat terjadi walaupun tanpa disertai infeksi sekunder. Selain itu pula dapat ditemukan anemia ringan dan trombositopenia. $^{8}$

Pemeriksaan serologis dilbedakan menjadi uji Widal $(+)$ dan uji Tubex $(+)$ dengan hasil pemeriksaan serologis uji Widal $(+)$ terdapat $89 \%$ dan uji Tubex $(+)$ terdapat $11 \%$. Pasien demam tifoid harus mendapat cairan yang cukup, yang mengandung elekrolit dan kalori yang optimal. Terapi cairan diberikan kepada semua pasien yaitu $\mathrm{RL}(85 \%)$ dan $\mathrm{NaCL}(15 \%)$.

Uji widal (+) akan memperkuat dugaan pada penderita Demam tifoid. Uji widal $(+)$ pada penderita demam tifoid apabila diagnosa ditemukan titer $O 1 / 320$, sedangkan uji widal (-) pada penderita demam tifoid dapat terjadi karena faktor-faktor yang berhubungan dengan penderita seperti pengobatan dini dengan antibiotik sebelumnya, waktu penganmbilan darah, reaksi vaksinasi, dan faktor teknik pengambilan darah. ${ }^{1}$

Pada penderita demam tifoid, pemberian obat terdiri dari pemberian obat antibiotik dan simtomatik. Pemberian antibiotik oral yang tertinggi yaitu Tiamfenikol (45\%) dan terendah Kotrimoksazol (5\%) (Tabel 4).

Tabel 4. Proporsi pasien demam tifoid rawat inap berdasarkan pemberian obat dan perawatan $(n=100)$ 


\begin{tabular}{lcc}
\hline \multicolumn{1}{c}{ Karakteristik } & n & $\%$ \\
\hline Antibiotik Oral & & \\
$\quad$ Kloramfenikol & 25 & 25 \\
$\quad$ Tiamfenikol & 45 & 45 \\
$\quad$ Kotrimoksazol & 5 & 5 \\
$\quad$ Sefriakson & 25 & 25 \\
Lama rawatan $(X ; S D=5,78 ; 2,008)$ & & \\
$\quad$ Minimum & 2 & \\
$\quad$ Maksimum & 12 & \\
Keadaan sewaktu pulang & & \\
$\quad$ Sembuh & 10 & 10 \\
$\quad$ Rawat jalan & 49 & 49 \\
$\quad$ Pulang atas permintaan sendiri & 40 & 40 \\
$\quad$ Meninggal & 1 & 1 \\
\hline
\end{tabular}

Obat untuk demam tifoid yang sering digunakan saat ini yaitu kloramfenikol, tiamfenikol, kotrimoksazol, ampisilin dan amoksisilin, sefalosporin generasi ketiga, fluokuinolon dan azitromisin. ${ }^{8}$ Sejak diperkenalkan, kloramfenikol telah menjadi standar emas antimikroba untuk pengobatan. Tidak ada obat yang telah begitu baik menunjang reaksi klinis yang diharapkan, yang biasanya mejadi nyata dalam waktu 24 sanpai 48 jam setelah dimulainya pengobatan dalam dosis yang sesuai ( 3 sampai $4 \mathrm{~g} /$ hari pada orang dewasa atau 50 sampai $75 \mathrm{mg} / \mathrm{kg}$ BB per hari pada anak yang lebih muda). ${ }^{10}$

Lama rawatan merupakan lamanya penderita demam tifoid menjalani perawatan di rumah sakit, dihitung sejak tanggal mulai dirawat sampai dengan tanggal keluar seperti yang tercatat di kartu rekam medik pasien. Lama rawatan rata-rata adalah $5,78=6$ hari. Lama rawatan minimum 2 dan maksimum adalah 12 hari.

Keadaan sewaktu pulang merupakan keadaan atau kondisi pasien demam tifoid ketika meninggalkan rumah sakit. Keadaan sewaktu pulang terdiri dari sembuh, pulang berobat jalan, pulang atas permintaan sendiri dan meninggal dunia. Keadaan sewaktu pulang terbanyak Rawat Jalan (49\%), Pulang Atas Permintaan Sendiri $(40 \%)$, Sembuh (10\%) dan Meninggal (1\%). Tidak dapat diketahui komplikasi yang terjadi karena di dalam rekam medik tidak tercatat. Komplikasi dapat terjadi di dalam usus (intestinal) seperti perdarahan intestinal dan perforasi usus. Komplikasi di luar usus (ekstraintestinal) seperti komplikasi hematologi, komplikasi tifosa, komplikasi pankreatitis tifosa dan miokarditis. ${ }^{8}$

\section{KESIMPULAN}

Penelitian ini menyimpulkan keluhan utama tertinggi pada pasien demam tifoid adalah demam $(91 \%)$ dan keluhan tambahan tertinggi mual (76\%). Berdasarkan jenis pemeriksaan, pemeriksaan fisik yang tertinggi adalah pemeriksaan pada lidah tifoid $(68 \%)$, pemeriksaan darah rutin yang tertinggi dengan leukopenia (65\%). Pemeriksaan serologis pada semua pasien yaitu uji widal (+) $89 \%$ dan uji tubex (+) $11 \%$. Terapi cairan diberikan kepada semua pasien yaitu terapi $\mathrm{RL}(85 \%)$ dan $\mathrm{NaCL}$ (15\%). Sedangkan pada lama rawatan, rata-rata 6 hari (minimum 2 hari dan maksimum 12 hari). Outcome perawatan paling banyak adalah pulang berobat jalan (49\%). Status komplikasi tidak tercacat sehingga disarankan untuk lebih memperhatikan kelengkapan pada status data rekam medis.

\section{REFERENSI}

1. Widoyono, 2011. Penyakit Tropis. Edisi 2. Penerbit Erlangga: Jakarta.

2. WHO, 2003. Background document: The Diagnosisi, Treatment and Prevention of Typhoid Fever. Geneva, Switzerland.

3. Nasronudin, Hadi U, Vitanata, Erwin AT. 2011. Penyakit Infeksi di Indonesia \& Solusi Kini Mendatang. Airlangga University Press: Surabaya

4. Departemen Kesehatan. 2012. Profil Kesehatan Indonesia 2012. Jakarta.

5. Dinas Kesehatan Propinsi Sumatera Utara. 2010. Profil Kesehatan Propinsi Sumatera Utara 2009. Kota Medan.

6. Zulkoni A. 2011. Salmonella Typhosa Penyebab Tipes. Nuha Medika: Yogyakarta.

7. Irianto K. 2014. Bakteriologi Mikologi \& Virologi. CV Alfabeta: Bandung.

8. Setiati S, Alwi I, Sudoyo AW, Stiyohadi B, Syam AF. 2014. Buku Ajar IImu Penyakit Dalam Jilid I. Jakarta: Interna Publishing

9. Nainggolan RNF. 2009. Karakteristik Penderita Demam Tifoid Rawat Inap di Rumah Sakit Tentara TK-IV 01.07.01 Pematang Siantar. FKM USU

10. Keusch GT. 1999. Prinsip - Prinsip IImu Penyakit Dalam Harrison, Volume II. EGC: Jakarta 